\title{
MIESTŲ MEDINĖS ARCHITEKTŪROS IŠSAUGOJIMO GALIMYBĖS
}

\author{
Nijolè Lukšionytè \\ Vytauto Didžiojo universitetas, Menu fakultetas, \\ Laisvès al. 53, 44309 Kaunas, Lietuva \\ El.paštasn.luksionyte@mf.vdu.lt \\ Iteikta 20110310
}

\begin{abstract}
Santrauka. Paveldosaugos institucijos Lietuvoje nuo $2002 \mathrm{~m}$. deklaruoja medinès architektūros išsaugojimo būtinumą, tačiau realių rezultatų pasiekta labai nedaug. Vilniaus miesto savivaldybès iniciatyva parengta medinès architektūros apsaugos strategijos programa kol kas nedave apčiuopiamų rezultatų.

Straipsnis skirtas Kauno medinės architektūros išsaugojimo poreikių ir galimybių analizei. Kaune išliko medinių dvarelių, sodybinių namų, vilų, kotedžų, vasarnamių, nuomojamų namų, kariškių ir geležinkeliečių gyvenamụjų kompleksų. Reikètų išsaugoti šių tipologinių grupių architektūros reprezentantus visose miesto dalyse. Jie atspindi profesionaliosios ir etninès (miesto, dvaro, kaimo) tradicijų jungtị ir dèl to yra išskirtiniai lokalinio tapatumo perdavejai.

VDU Menų fakultete $2009 \mathrm{~m}$. vykdytas edukacinis projektas atskleidè, jog medinių namų išlikimas daugiausia priklauso nuo savininkų motyvacijos. Savininkų patraukimas ị medinio paveldo rẻmėjų pusę laikytinas svarbiausia išsaugojimo sąlyga. Būtina organizuoti konsultavimą apie paveldui palankią namų priežiūrą ir tvarkymą. Medinių namų atgaivinimu suinteresuota bendruomenė galètų kurtis ir dalintis informacija virtualioje aplinkoje.
\end{abstract}

Reikšminiai žodžiai: mediniai namai, architektūros paveldas, Kaunas.

\section{Ivadas}

Apie senosios medinès architektūros savitumą ir medžio statybos tradicijos vertę dažnai kalbama oficialiuose Lietuvos paveldosaugos dokumentuose, specialistų darbuose ir populiarioje publicistikoje. Lietuva, kaip ir Skandinavijos kraštai, vadinama medžio kultūros šalimi, nes čia, skirtingai nuo Vakarų Europos, ši tradicija išliko gyvybinga iki XX a. vidurio. Meno istorikai randa rimtų argumentų, jog Lietuvoje bei Lenkijoje statyba iš medžio turèjo įtakos formuojantis mūrinei gotikos architektūrai (Sokołowski 1906: 35-40; Drèma 1991: 88, 97). Dauguma Vakarų Europos miestų medinès statybos kvartalų neteko XIX a., pramoninès revoliucijos metu. Šiaurèje išliko Brygenas (Bergeno senamiesčio dalis), Norvegijos kalnakasių miestas Røros. Medinè architektūra čia kruopščiai prižiūrima ir saugoma.

Medžio paveldui Lietuvoje atstovauja sakralinè architektūra, kryždirbystès reliktai, provincijos dvarai, senosios kaimo sodybos, taip pat miestų ir miestelių gyvenamieji namai. Kiekvienos objektų grupès iš- saugojimo ir atgaivinimo problemos kiek skirtingos. Kaimų, dvarų pastatai apleisti ir labiausiai kenčia nuo socialinès aplinkos pasyvumo. Miestų mediniai namai (ypač Vilniaus ir Kauno) - priešingai - patiria kaitos ir naikinimo pavojų, nes nekilnojamojo turto renovacija čia plečiasi lyg upè pavasario polaidžio metu. Miestuose išliko palyginti nemažai medinių pastatu. Kažkam jie - egzotiški reliktai, kitiems - iprastas būstas, kurị norima padaryti šiltesnį ir patogesnị, tretiems - kliūtis pletros kelyje. Vis dar yra manančių, jog „medinès lūšnos" menkina didmiesčių prestižą. Tačiau priešingos nuomonès atstovų pamažu daugèja.

Niekam ne paslaptis, kad didžioji dalis trapaus, itin atidžios priežiūros reikalaujančio medinio paveldo yra kritinès būklès. Ką šiuo klausimu oficialiai deklaruoja Lietuvos paveldo apsaugos teisè bei ją vykdančios institucijos? Ar reali didžiųjų miestų medinès architektūros išlikimo galimybè? Ką galima pasiūlyti miestų medinès architektūros gaivinimo labui? Šiame tekste remiamasi Kauno medinès architektūros pavyzdžiais, kurie iki 
šiol nepakliuvo ị apsaugos strategijų ir programų dèmesio lauką. Straipsnio tikslas - kiek galima objektyviau ìvertinti Kauno medinès architektūros išsaugojimo poreikius ir galimybes.

Miestų medinè architektūra Lietuvoje tyrinèta arba istoriniu ir menotyriniu aspektu, arba praktiniais (išsaugojimo) tikslais. Apie Vilniaus ir Kauno medinius pastatus istorizmui ir modernui skirtuose leidiniuose yra tekę rašyti šių eilučiu autorei (Lietuvos architektūros istorija 2000: 141-147, 173-177, 220-222, 450-452; Lukšionytė-Tolvaišienè 2000: 103-133, 2001: 137-154). Vilniaus Užupio namus plačiau nagrinèjo J. Jurevičienè (2002), Žvèryno - M. Ptašek (1993, 2002). Minètos autorès tyrè medinès architektūros raidą ir tipologiją bei stilistiką, taip pat atkreipè demesi $i$ apsaugos problemas. Pažintinį aspektą skatina Kultūros paveldo departamentas, kurio iniciatyva išleistas straipsnių rinkinys Mediné architektūra Lietuvoje (2002), jame specialistai apžvelgia kaimo namus, dvarų sodybas, bažnyčias ir sinagogas, kryždirbystę, Klaipèdos krašto bei kurortu medinius pastatus. Papildytą knygos versiją, kurioje įtraukti ir miestų namai, departamentas ruošiasi išleisti anglų kalba. Vizualią pažintị su Vilniaus ir Kauno mediniais namais fotografijų albumuose pateikia dailininkas A. Surgailis $(2006,2008)$.

Tiek Vilniuje, tiek Kaune daryta taikomojo pobūdžio tyrimų, kurie nera publikuoti ir žinomi tik specialistams. Architektūros ir statybos instituto mokslininkai A. Miškinis ir N. Steponaitytè vertino viso Kauno medinius pastatus, remdamiesi apžiūra natūroje (Miškinis, Steponaitytė 1995). Su grupe pagalbininkių pačiai yra tekę tirti ir vertinti dviejų teritorijų architektūros paveldą: 2002 m. parengtas Žaliakalnio dalies prie Gèlių ir Minties ratų apsaugos reglamentas, 2007 m. - kitos Žaliakalnio dalies tarp Perkūno ir Kauko alejų tyrimas ${ }^{1}$. Abiejose Žaliakalnio dalyse gausu medinių namų. Reglamento tema paskelbtas mokslinis straipsnis (Lukšionytė-Tolvaišienė 2005). Vilniaus medinè architektūra savivaldybės užsakymu plačiai tyrinèta ir fiksuota rengiant apsaugos strategijos matmenis (Filipavičienè ir kt. 2004; Puodžiukienè ir kt. 2005).

\section{Kauno medinès architektūros resursai}

Remiantis sukauptų istorinių ir natūros tyrimų analize, galima daryti išvadą, jog tipologijos požiūriu me-

\footnotetext{
1 Kauno miesto istorines dalies, vadinamos Žaliakalniu (U 31) apsaugos reglamentas (kartu su K. Šilinyte, A. Tatariūniene, J. Butkevičiene). 2002. T. 1-3 (su priedais). Kauno miesto savivaldybès 1-ojo Žaliakalnio kultürinio draustinio specialiojo plano pagrindžiamoji dalis: Kultūrinio draustinio teritorijos tyrimai, paveldosauginiu verčiu nustatymas ir pasiūlymai saugojimui. 2007. 130 p., 8 brèž.
}

diniai Kauno namai ịvairesni nei Vilniaus. Tarpukariu Vilniuje medinukų beveik nebestatyta, o Kaune tuo metu buvo pats jų klestejimo metas. Skirtinos 8 medinių namų tipologinès grupès, atstovaujančios dviems laikotarpiams - carizmo ir tarpukario. Jos tokios:

- XIX a. vidurio „dvareliai“ miesto pakraščiuose: charakteringi jų atstovai išlikę Būgos g. 4 (Naujamiestis, statytas apie 1850 m.), A. Mackevičiaus g. 96, 1885 m. (Ąžuolų kalnas), Radvilų dvaro g. 1a, 1 (Vilijampolè), Veiverių g. 18 (Aleksotas).

- XIX a. pabaigos - XX a. pradžios miestiečiu namai: pvz.: K. Donelaičio g. 5 (1896 m., Naujamiestis), D. Poškos 7/Trimito g. 8 (Naujamiestis), Pušyno g. 27 (Šančiai), Jurbarko g. 10 (Vilijampolè).

- Tipizuoti XIX a. pabaigos kariškių namai (Juozapavičiaus pr. 15, Šančiai, Lakūnų pl. 46, Aleksotas) bei geležinkeliečių namai (Juozapavičiaus pr. 124b, Juozapavičiaus pr. 125, 131, Šančiai, Tunelio g. 17 ir Čiurlionio g. 18, Naujamiestis).

- Tarpukario sodybiniai nameliai Žaliakalnyje, Šančiuose, Vilijampolëje: Kudirkos g. 6, Kraševskio g. 7 (Žaliakalnis), Kranto al. 77, 89 (Šančiai), Vidurinè g. 15, Kernavès g. 18 (Vilijampolè).

- Tarpukario nuomojamų butų namai: Minties rato g. 24, M. Jankaus g. 32 (Žaliakalnis), Jurbarko g. 73 (Vilijampolè).

- Tarpukario vilos: Žemaičių g. 20 (Žaliakalnis), A. Smetonos al. 75 (Panemunè), Planetų g. 15 / Sietyno g. 17 (Linksmadvaris).

- 4 dešimtmečio modernistiniai kotedžai - Minties rato g. 51 (Žaliakalnis), Gailutès g. 19 (Panemunè).

- Vasarnamiai Panemunès kurorte - Gailutès g. 28,

A. Smetonos al. 29, A. Smetonos al. 81.

Seniausi yra Naujamiesčio mediniai namai, jų likę nedaug (didelè dalis nugriauti arba neatpažístamai pakeisti). Patys archajiškiausi - mediniai dvareliai Naujamiesčio pakraščiuose; juos erdviuose sklypuose statėsi į miestą persikeliantys bajorai. Dauguma dvarelių sunaikinti, îspūdingiausias išlikęs - apie $1850 \mathrm{~m}$. datuojama Kauno burmistro rezidencija (1 pav.) K. Būgos g. 4 (vidus perplanuotas ị butus 1929 m.). Dvareliai būdavo renčiami ant aukšto mūrinio cokolio, turèdavo rūsius, prieangius su kolonomis (neišlikęs Kartofliškių palivarko namas).

Miestiečiu namai (2, 3, 4 pav.) pailgi, statyti šonu i gatvę, dengti dvišlaičiais skardos stogais, rąstų sienos cokolinejje dalyje apkaltos lentelèmis vertikaliai, likusi dalis - horizontaliai, langai su langinèmis (Donelaičio g. 5, Karo ligoninès g. 9, D. Poškos g. 7). Tai sodybinio pobūdžio namai. Jie taip pat vyrauja buvusiuose Kauno priemiesčiuose. Siaurose, padrikose Vilijampolès gatvelèse įsikūrę žydai statėsi nedidelius 


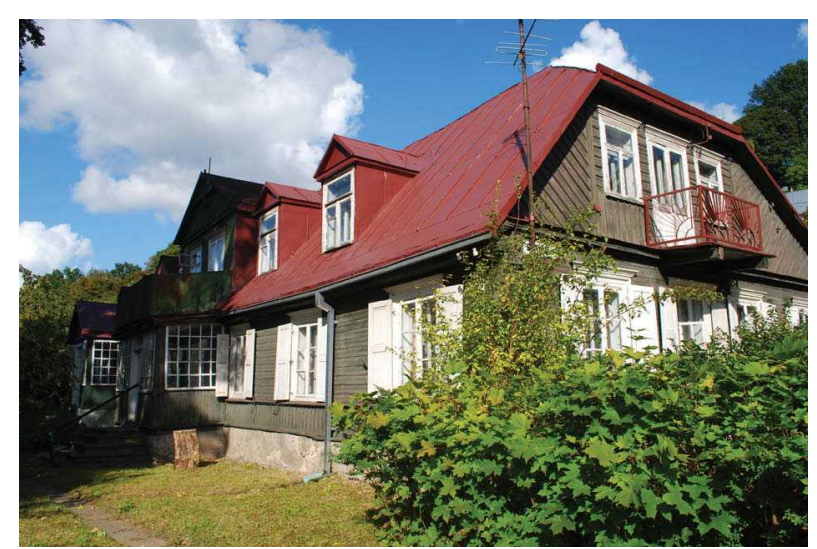

1 pav. XIX a. vidurio dvarelis Būgos g. 4

Fig. 1. The wooden manor in Būgos g. 4

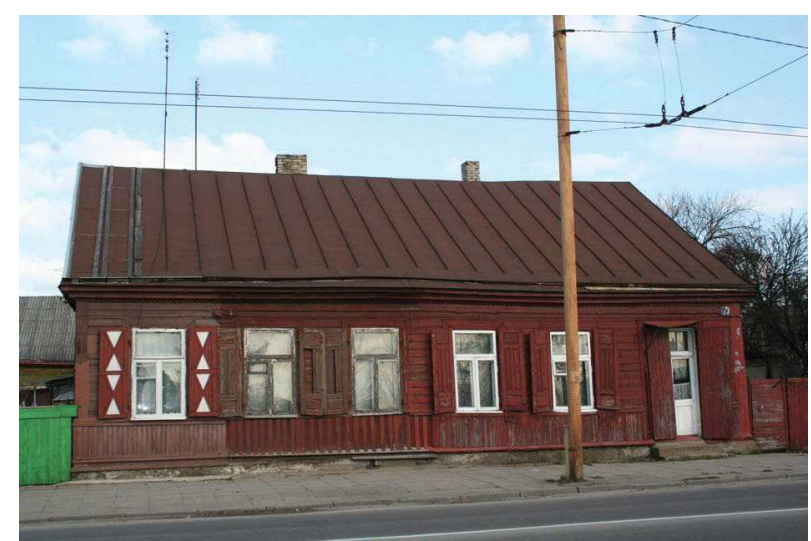

2 pav. XIX a. pabaigos miestiečio namas Vilijampoleje, Jurbarko g. 10

Fig. 2. A house of a townsman in Vilijampolè, Jurbarko g. 10, end of the XIX C.

namus su krautuvèlèmis. Vieni iš jų atgręžti i gatvę šonu, kiti - galu, durys tiesiai iš gatvès, langai su langinèmis. Žemųjų Šančių priemiestis kūrèsi 1862 m. nutiesus geležinkelị - čia steigesi fabrikai, apsigyveno darbininkai. Nemuno pakranteje nutiestos gatvelès palaipsniui apstatytos mediniais nameliais nedideliuose sklypuose. Šančiuose labiausiai paplitę vientiso tūrio sodybiniai namukai (5-6 pav.), kai kurie su atvirais prieangiais arba verandomis, su langinemis. Tarpukariu daug sodybinių namų pastatyta Žaliakalnyje. Jie stačiakampio plano, vieno arba dviejų butų, kai kurie paaukštinti mezoninais, mansardomis, kiti turi ịstiklintas verandas. Atviri prieangiai būna su profiliuotomis medžio kolonèlemis. Pasitaiko verandų, kurių langai suskaidyti geometrinio piešinio rèmais, švyti spalvotais stiklais. Išraiškingumo suteikia langinès, sandrikai, apylangès, frontonèliai, piliastrų imitacijos, kiaurapjūvių lentelių dekoras. Nors namų tūriai giminingi lietuvių etninei tradicijai, tačiau dekoras kartais artimas klasicizmo, baroko, Art Nouveau stilistikai.
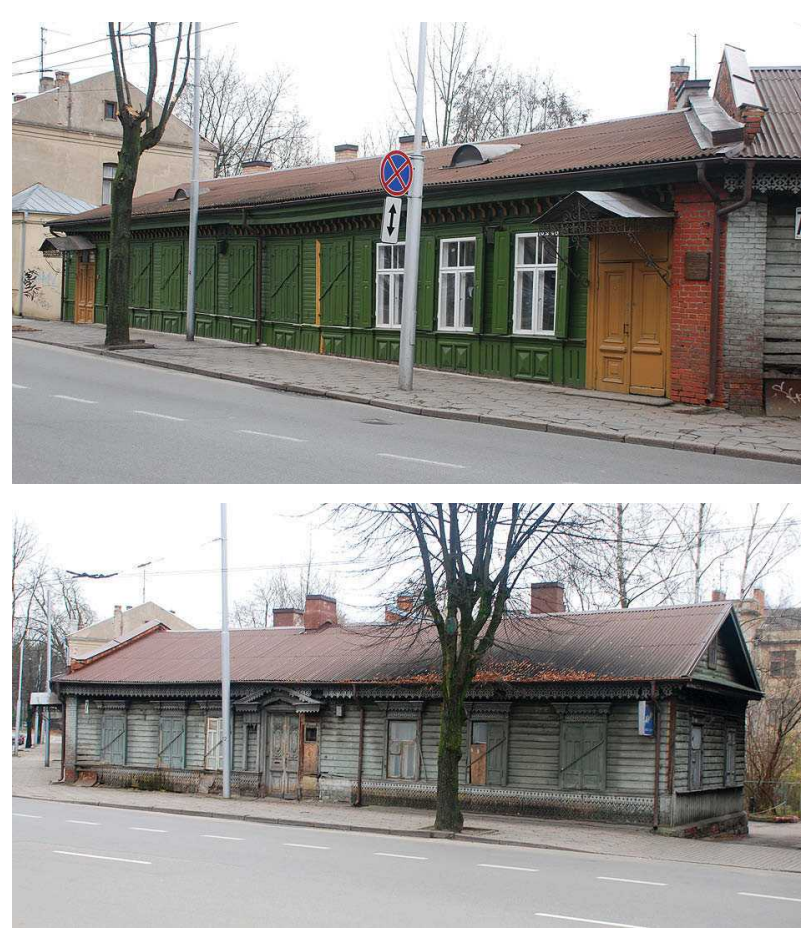

3, 4 pav. Miestiečiu namai Naujamiestyje, Donelaičio g. 5 (1896 m.) ir Donelaičio g. 7 (1895 m.)

Figs 3, 4. Houses of townsmen in Naujamiestis, Donelaičio g. 5 ir Donelaičio g. 7
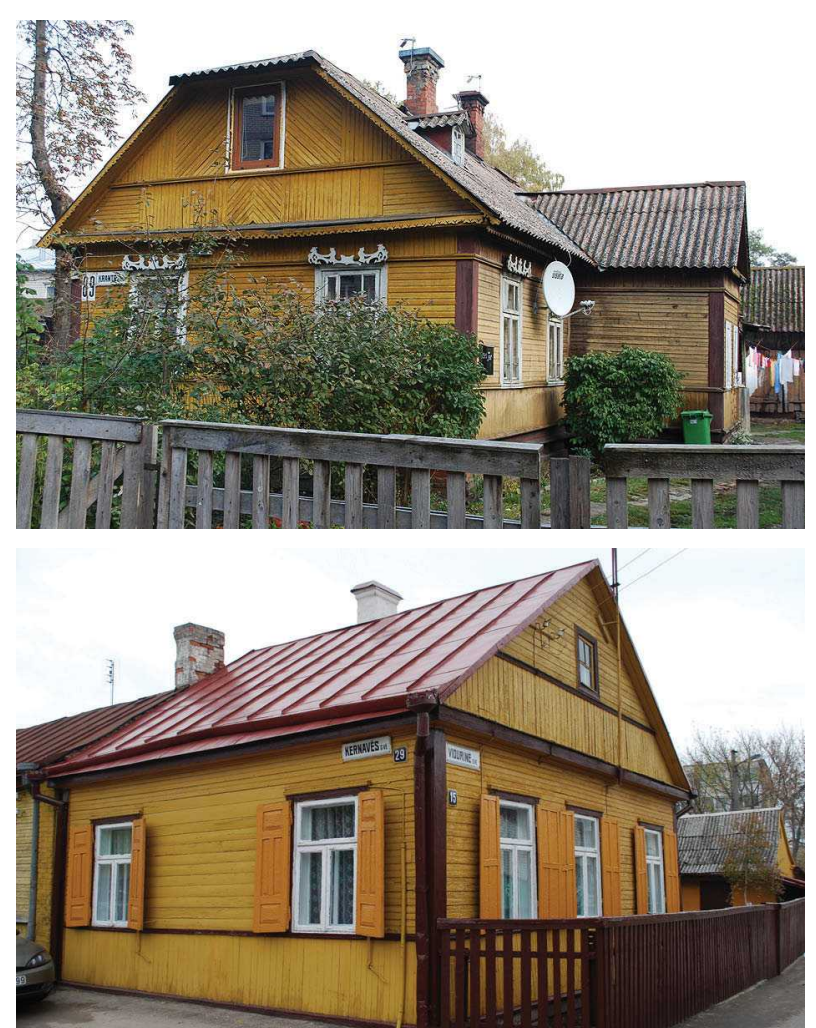

5, 6 pav. Sodybiniai namai Šančiuose, Kranto al. 89, ir Vilijampoleje, Vidurinè g. 15

Figs 5, 6. Garden houses in Šančiai, Kranto al. 89 and Vilijampolè, Vidurinè g. 15 
Šančiai gali pasigirti mediniais karinès tvirtovès puskarininkių bei geležinkelio tarnautojų namais (7, 8 pav.), statytais XIX a. pabaigoje. Taupumo sumetimais naudoti keli tipizuoti tūrio ir dekoravimo variantai. Kitas paplitęs medinès statybos tipas - dviaukščiai gyvenamieji namai, kuriuose būdavo po 4 arba daugiau nuomojamų butų $(9,10$ pav.). Tai ekonomiškų būstų namai, išorèje paprastai nedekoruoti, sienos karkasinès, apkaltos lentelèmis. Tokių namų paplitimą galèjo skatinti lakoniška Skandinavijos šalių medinè architektūra.

Kiaurapjūvis medžio dekoras istorizmo laikotarpiu buvo populiarus daugelyje Europos regionų, ypač slavų kraštuose. Tačiau būtume neteisūs, miestų namuose neįžvelgdami sąsajų su lietuvių kaimo trobesių puošyba. Dzūkijos, Aukštaitijos regionams artimų antlangių, karnizų, vejjalenčių pasitaiko Vilniaus namų dekore. Kaune modifikuotų etninių motyvų sutinkama Šančių (Kranto al. 89), Panemunès (Upelio g. 30), Žaliakalnio

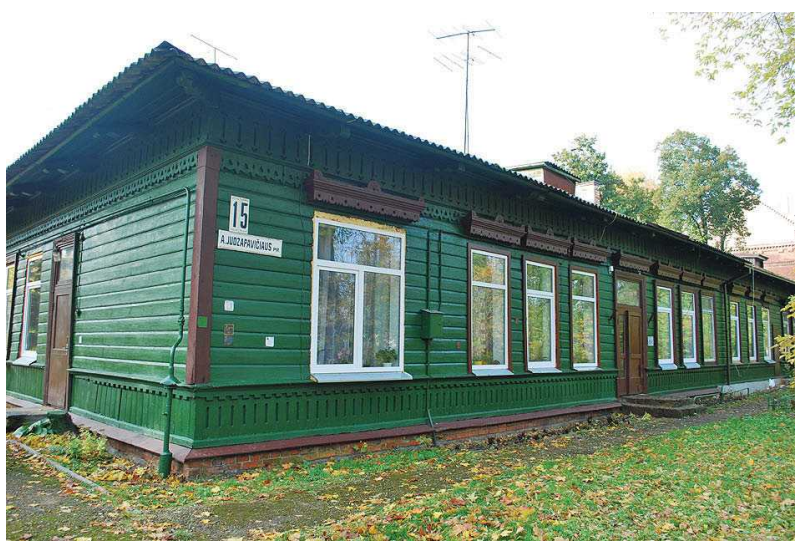

7 pav. Puskarininkių namas Šančiuose, Juozapavičiaus pr. 15

Fig. 7. Warrant-officer house in Šančiai, Juozapavičiaus pr. 15

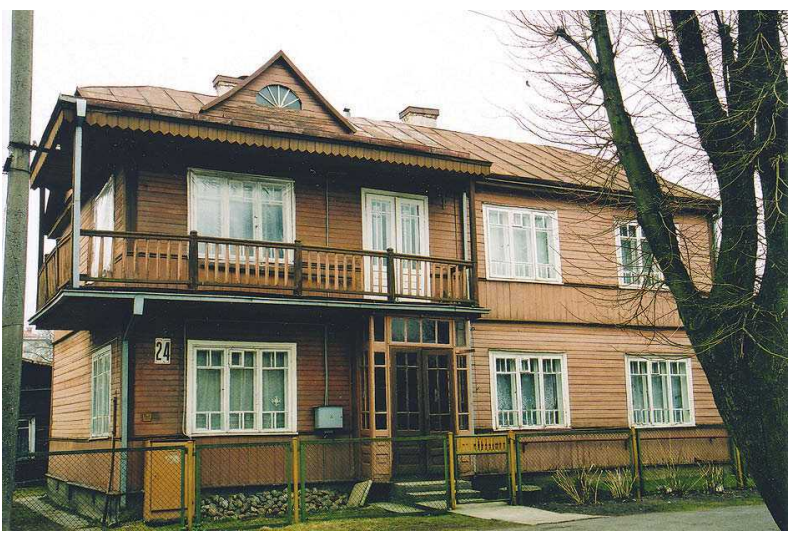

architektūroje (J. Kraševskio g. 7, 1925 m.). Rusiško stiliaus motyvai panaudoti Igulos Soboro statybos rangovo Logino Ščerbakovo namuose (Donelaičio g. 7 ir 11). Šiuos itin puošnia mezginių ornamentika dekoruotus namus $1895 \mathrm{~m}$. statè dailidès, pakviesti iš Černigovo gubernijos. Greta esantis medinis Rudolfo Markerio namas (K. Donelaičio g. 5, 1896 m.) turi visiškai kitoki - neoklasicizmui artimu formu - dekorą. Fredoje esančiu carinès armijos kariškių namų dekore pasitaiko motyvu, perimtų iš vadinamojo šveicariško stiliaus (Lakūnų pl. 46). XIX a. pabaigos geležinkelio tarnautojų namuose netoli stoties rusiški drožiniai ir langų apvadai derinami su šveicariškam stiliui būdingais profiliuotais gegnių galais, kryžmai sunertais elementais pastogèse (Tunelio g. 17, A. Juozapavičiaus pr. 124c, $125,131)$

Tarpukariu suklestėjo Panemunès kurortas, čia pastatyta išraiškingų medinių vilų, jos beveik visos išlikusios. Tik architekto S. Kudoko projektuotas me-

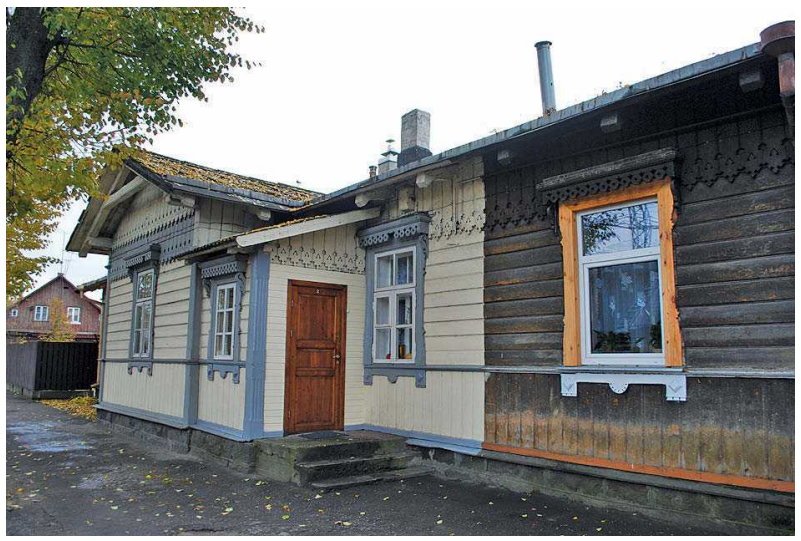

8 pav. Geležinkelio tarnautoju namas Šančiuose, Juozapavičiaus pr. 125

Fig. 8. House of employees of the railroad in Šančiai, Juozapavičiaus pr. 125

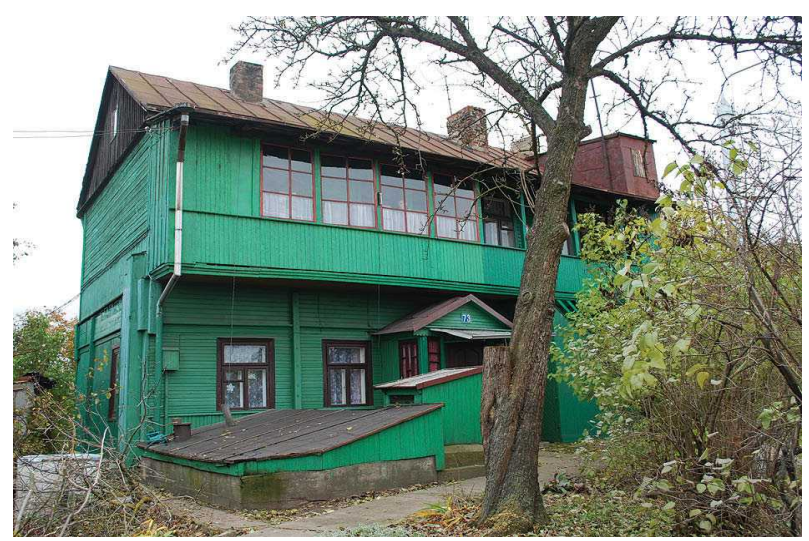

9, 10 pav. Nuomojamų butų namai Žaliakalnyje, Minties rato g. 24 (1928 m.) ir Vilijampoleje, Jurbarko g. 73

Fig. 9, 10. Rental houses in Žaliakalnis, Minties rato g. 24 and Vilijampolè, Jurbarko g. 73 
dinis kurhauzas sudegè. Vilos statytos vienos šeimos poreikiams, o vasarnamiai būdavo nuomojami poilsiautojams. Jie dviaukščiai, imponuoja stambiais tūriais; būdingas pavyzdys - Gailutès g. 28 (1926 m.) vasarnamis su šešiakampiais rizalitais, kurių kupoliniai stogai primena bokštelius (11 pav.).

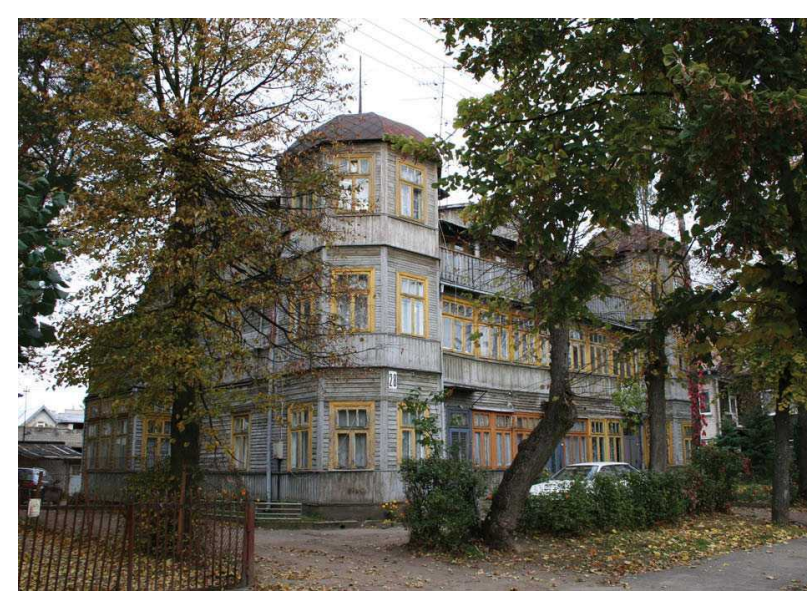

11 pav. Vasarnamis Panemunès kurorte, Gailutès g. 28

Fig. 11. A summer house in the resort of Panemunè, Gailutès g. 28
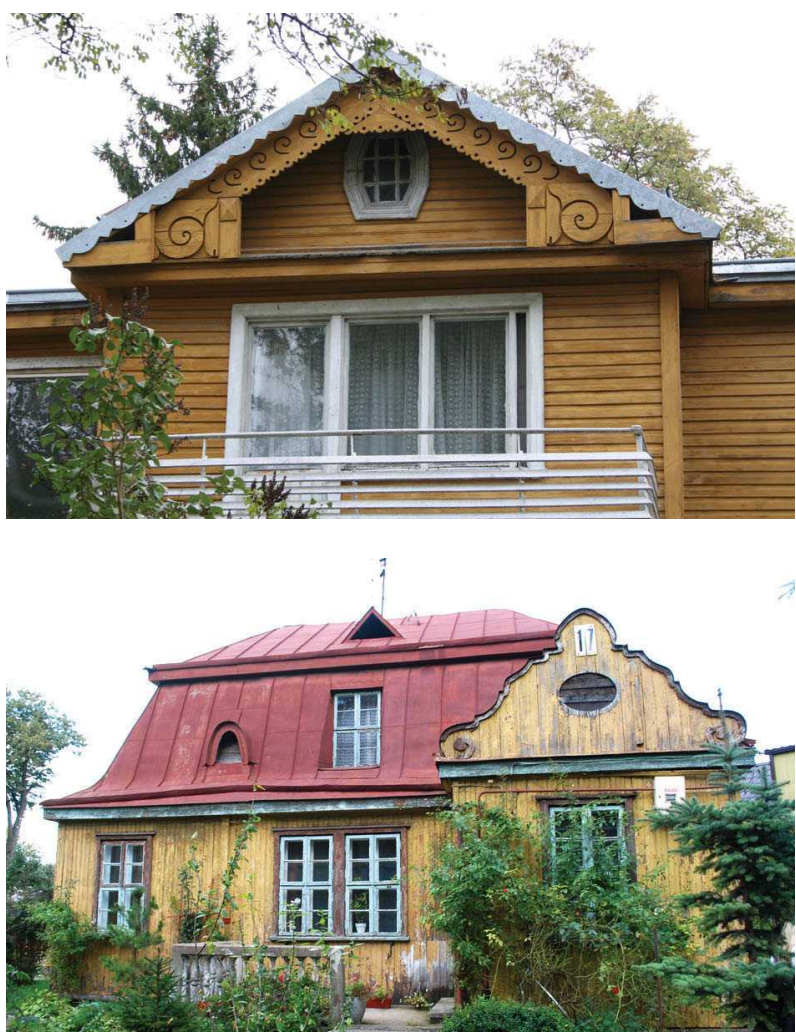

12, 13 pav. Baroko interpretacijos tarpukario vilose: Panemuneje, Gailutès g. 19; Žaliakalnyje, Minties rato g. 2/17

Figs 12, 13. Baroque interpretations in the interwar villas: Panemunè, Gailutès g. 19, Žaliakalnis Minties rato g. 2/17
XX a. 3 dešimtmetyje Kauno architektai buvo užsidegę tautinio stiliaus idejja. Kadangi Lietuvoje gilų pèdsaką paliko barokas, bandyta stilizuoti ir pritaikyti medžiui jo formas (12-15 pav.). Viloje K. Petrausko g. 23 panaudotas laužytas mansardinis stogas, aptakių formų bokštelio šalmas, prieangis su kolonèlemis. Architekto Antano Jokimo namas (Minties rato g. 2/17, $1924 \mathrm{~m}$.) turi neobaroko formų frontoną su voliutomis.

Iš medžio statyti ir visuomeninès paskirties statiniai, bet jie neišliko (restoranas miesto sode, koncertu paviljonai, arklių tramvajaus stotelès, laikini parodų statiniai, krautuvèlès). Mediniai namai dažniausiai būdavo išdèstomi erdviuose sklypuose, juos supo vaismedžių sodai, daržai. Medžio ir mūro statyba Kauno kvartaluose nebuvo atskirta, sudarè organišką dermę.

\section{Oficiali medinio paveldo apsaugos politika}

Valstybinè kultūros paveldo komisija, veikianti prie Lietuvos Respublikos Seimo, 2002 ir 2006 m. yra prièmusi sprendimus dèl medinio kultūros paveldo išsaugojimo. Komisija skatino inventorizuoti medinès architektūros objektus, kompensuoti paveldo šeimi-
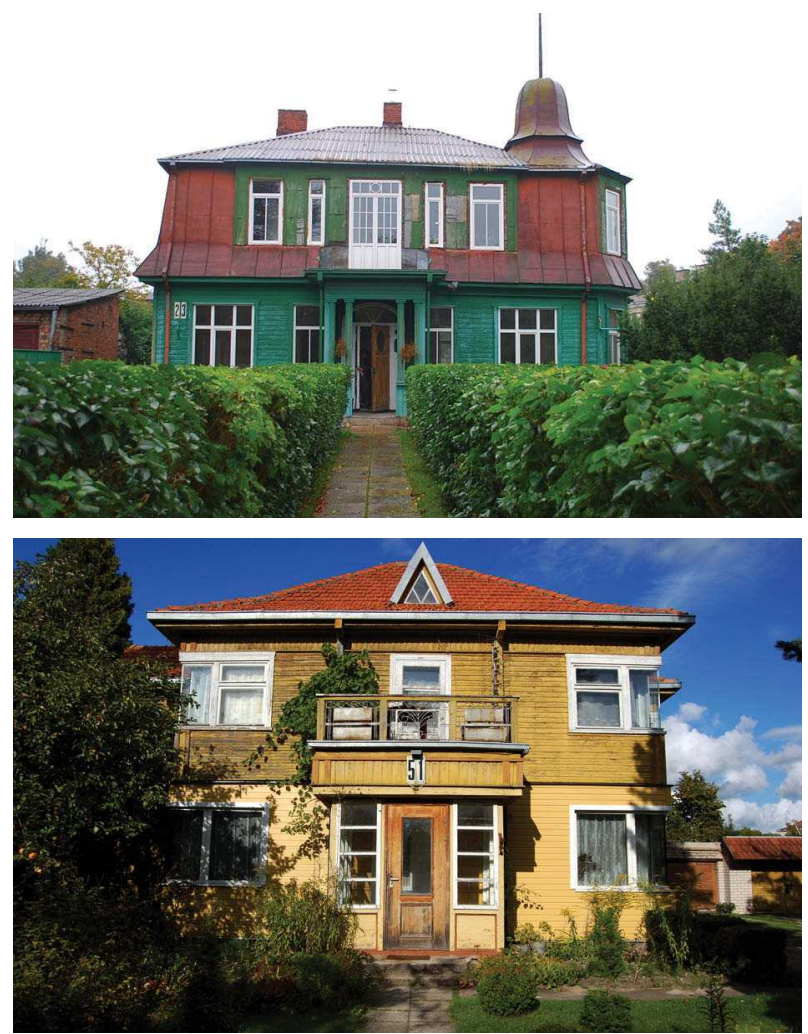

14, 15 pav. Vila Petrausko g. 23 (apie 1926 m.) ir modernistinis kotedžas Minties rato g. 51 (1935 m.): atliekami tvarkymo darbai tik iš dalies atitinka autentiškumo sąlygą

Figs 14, 15. Villa on Petrausko g. 23 , and modernistic cottage on Minties rato g. 51: dressing works carried out only partially comply with the condition of authenticity 
ninkams už kokybiškai atliktus tvarkymo darbus, savivaldybėse skirti tikslinị finansavimą medinei architektūrai.

Atsižvelgdama i komisijos sprendimus, Lietuvos Respublikos Vyriausybė 2006 m. prièmé nutarimą „Dèl Lietuvos Respublikos architektūros politikos krypčių igyvendinimo $2006-2010 \mathrm{~m}$. priemonių patvirtinimo". Jame numatyta parengti medinès architektūros paveldo išsaugojimo programą. Tokia programa, skirta 2008-2010 m. laikotarpiui, patvirtinta kultūros ministro įsakymu $2008 \mathrm{~m}$. sausio mèn. $24 \mathrm{~d}$. Joje pripažistama medinio paveldo išsaugojimo svarba, aprašoma esama jo būklè, numatomi apsaugos uždaviniai: parengti ir igyvendinti medinio paveldo apskaitos priemones, formuoti palankią teisinę aplinką, kryptingiau koordinuoti priežiūrą, tvarkybą ir naudojimą, parengti ir igyvendinti medinio paveldo pažinimo, sklaidos, atgaivinimo priemones. Remiantis programa suorganizuotas tradiciniams amatams mokyti skirtas seminaras (2009 m. spalio mèn. Rumšiškèse), konferencija (2010 m. balandžio men. 26, 27 d. Vilniuje), ruošiamasi išleisti straipsnių rinkini anglų kalba. Tačiau didžioji dalis numatytų darbų - rutininio pobūdžio (objektų ịrašymas ị registrą, kultūros vertybių klasifikatoriaus tobulinimas, įstatymo ịgyvendinamųjų aktų keitimas, tvarkybos reglamentų parengimas), jie turètų būti atliekami ir be specialios programos. Sprendžiant iš 2008-2010 m. rezultatų, nepanašu, jog būtų pagerejusi medinių pastatų būklè, ịsižiebęs visuomenès domejjimasis mediniu paveldu ar sukurta patraukli terpè tarptautiniam turizmui. Atrodo, jog laikas ir lëšos dažnai eikvojami formalioms užduotims. 2009 m. Kultūros paveldo departamentas užbaigè medinès architektūros objektų stebėseną - buvo apžiūrèti vertybių registre esantys objektai, užpildytos detalios anketos, suvesti statistiniai duomenys. Darbas nepaprastai imlus, natūroje apžiūrèta daug objektų, tačiau nepasinaudota galimybe kartu užfiksuoti neregistruotus pastatus, galbūt unikalius, gal nesulauksiančius kitos apžiūros.

Lietuvos Respublikos Vyriausybès ir Kultūros ministerijos lygmenyje deklaruojama, jog medinès architektūros paveldas reprezentuoja kultūrinị tapatumą ir turi būti išsaugotas, tačiau jokių skubių priemonių nesiimama. Tai matydama, $2010 \mathrm{~m}$. Valstybinè kultūros paveldo komisija prièmé dar vieną sprendimą (2010 m. balandžio mèn. 30 d.). Jame konstatuojama, jog nevykdomi medinio paveldo išsaugojimo bei palaikymo tikslai, iškelti Nacionalinëje darnaus vystymosi strategijoje ir kituose bendro pobūdžio dokumentuose, etnografiniams kaimams neparengta nauja ilgalaike išlikimo programa, nenumatytas finansavimas, nèra paveldo priežiūros, tyrimų ir tvarkymo metodikų, nesukurta palankaus kreditavimo, kompensavimo už atliktus tvarkybos darbus sistema, neskatinama nuolatinè priežiūra. Valstybinè kultūros paveldo komisija pakartotinai ragina visas institucijas igyvendinti jos 2002 ir 2006 m. sprendimuose pateiktus siūlymus. Vadinasi, jau dešimt metų kalbama apie opią problemą, bet tai neskatina esminių pasikeitimų.

\section{Vilniaus pavyzdys: strateginis saugojimo planas ir reali veikla}

Vilniaus medinè architektūra specialistų laikoma vertinga ne tik Lietuvos, bet ir Europos paveldo kontekste. Miesto centrinèje dalyje išlikę apie 2000 medinių pastatų. Teisinis jų saugojimo pagrindas - Vilniaus miesto tarybos $2006 \mathrm{~m}$. balandžio $26 \mathrm{~d}$. sprendimu patvirtinta Medines architektūros paveldo apsaugos strategijos igyvendinimo programa $(2006 \mathrm{~m}$. balandžio 26 d.). Tai ambicingas dokumentas - tikimasi, kad jo „igyvendinimas sustabdys beatodairišką medinès architektūros ir jos aplinkos naikinimą, sudarys galimybę išlikti ypač vertingiems medinès architektūros statiniams ir jų grupems bei juos atkurti, pakeis visuomenès ir jai atstovaujančių institucijų požiūrị i medinę architektūrą kaip ị bevertị laikiną paveldą" (Bendroji dalis). Esamos būklès analizèje ịžvalgiai pastebèta, jog medinès architektūros nykimas labiausiai priklauso nuo požiūrio ị šios statinius kaip ị neprestižinius ir trumpalaikius, medinio paveldo kultūrinès vertès nesuvokimas, sparti miesto plètra (kuriai nepasirengta), itin didelè medinio statinio restauravimo arba atkūrimo kaina, išmanančių specialistų ir amatininkų stoka, taip pat finansinès ir teisinès medinio paveldo išsaugojimo politikos nebuvimas. Tenka tik pritarti, jog negatyvaus požiūrio ir vertès nesuvokimo veiksniai iš tikrųjų stipriau veikia medinio paveldo nykimą nei ekonominès ir teisinès priežastys. Vilniaus miesto savivaldybès administracijos Miesto pletros departamento užsakymu šios strategijos metmenis renge profesionalūs paveldo tyrejjai (Filipavičienè ir kt. 2004), atlikę didžiulį objektų analizès, klasifikavimo, vertinimo ir pasiūlymų formavimo darbą. Ypač vertingus objektus numatyta saugoti vietoje, vertingus, tačiau nepanaudojamus - perkelti ị specialiai sukurtą muziejų, o vidutinès vertès nepanaudojamiems objektams taikyti informacijos išsaugojimo metodą (kaupti fotofiksaciją, matavimo duomenis, statinių fragmentus). Numaty tos trejopos apsaugos priemonès: juridinès, ekonominès ir švietejjiškos. Pagal šią programą savivaldybė numato išsaugoti apie 200 medinukų (108 iš jų yra Žvèryne, mažesnès grupès - Šnipiškèse, Antakalnyje, Markučiuose, Rasose ir kitur). Suplanuota ịkurti Vilniaus miesto medžio kultūros centrą (muziejų). 
Programoje numatomos finansavimo mechanizmo sukūrimo galimybès, struktūrinių fondų bei privačių lèšų paieška. Numatyta daug švietejjiškų iniciatyvų, tarp ju - internetinio puslapio apie medžio paveldą sukūrimas, geriausiai tvarkomo, restauruoto bei atkurto objekto konkursai, iniciatyva „Išsaugokime senus langus" ir kt. Beje, paveldo specialistai yra suformulavę kiek neịprastą medinio pastato autentiškumo (t. y. pirmapradiškumo, tikrumo) traktavimą. Skirtingai nei mūro architektūroje, kur labai svarbu išsaugoti pirminę medžiagą, čia prioritetas teikiamas ne pačiai materijai, bet statybos tradicijai saugoti (KVAD... 2004). Atnaujinant namus turètų būti taikomos analogiškos medienos rūšys, tradicinès medžio apdorojimo technologijos, konstrukcijos. Sienojus, apkalus, dekorą galima keisti naujais analogiškais elementais. Tinkamai pakeitus, pastatas ir toliau bus laikomas autentišku.

Aptartosios Vilniaus medinès architektūros apsaugos programos igyvendinimas dèl ekonominių ir kitokių priežasčių sustojo tik èmęs įsibègèti. Pirmi darbai buvo pradèti $2005 \mathrm{~m}$.: restauruota triju namų (Filaretų g. 8, Baltasis skg. 7, Čiurlionio g. 33) išorè, atliktas 15-os unikalių pastatų dokumentavimas. $2006 \mathrm{~m}$. sutvarkyti vertingi pastatai Vytauto g. $27 \mathrm{ir}$ $63.2008 \mathrm{~m}$. atnaujinti medinukai Traidenio g. $35 \mathrm{ir}$ Pušų g. 16, 2009 m. - P. Skorinos g. 5. Iš savivaldybès lěšų atnaujinta 8 namų išorè (keturiems namams 50 proc. sąnaudų padengè patys savininkai). Medinių namų tvarkymą koordinuoja Vilniaus senamiesčio atnaujinimo agentūra, ịsteigta savivaldybès tarybos (<www.vsaa.lt $>$ ). Agentūros internetinèje svetainèje pateikta informacija apie restauruotus medinius namus, gyventojai skatinami teikti prašymus kompensuoti tvarkymo išlaidas (kompensavimas skiriamas tik tada, jei savininkai nepažeidžia paveldosaugos reikalavimų). Vilniaus senamiesčio atnaujinimo agentūra (VSAA) pradeda ugdyti motyvuotą bendruomenę - rengia konsultacinius seminarus gyventojams apie senamiesčio atgaivinimą, pastatų išorès ir aplinkos tvarkymą. Kartu su Oslo miesto savivaldybès paveldosaugininkais $2009 \mathrm{~m}$. organizavo du specialistų ir bendruomenių atstovų seminarus, paskelbẻ 10 patarimų medinių namų savininkams ir naudotojams (Vilniaus... 2006), planavo rengti Žvėryno ir Šnipiškių namų perdažymą, stogų tvarkymą, pasitelkiant jungtinį finansavimą (savivaldybè, privatūs rèmèjai, fondai).

Šiek tiek praktiškos informacijos apie medinių namų priežiūrą ir tvarkymą skelbia Kultūros paveldo departamentas. Jo tinklapyje pateiktos iš švedų kalbos išverstos elektroninès knygos apie rąstų namus, čerpių stogus, dažymą, langus (Jomantas). 2002 m. išleistoje knygoje „Medinè architektūra Lietuvoje“ taip pat yra praktinių patarimų skyrelis.

\section{Miesto medinès architektūros pažinimo akcija Vytauto Didžiojo universiteto Menų fakultete}

2009 m. rudens semestrą Vytauto Didžiojo universiteto Menų fakultete buvo vykdomas edukacinis projektas Medinès miesto architektūros pažinimas ir saugojimas, kuriame dalyvavo kultūros paveldo ir turizmo, meno istorijos ir kritikos bei Vilniaus Dailes akademijos Kauno Dailès fakulteto architektūros specialybių magistrantai.

Iškèlème tikslą susipažinti su realia Kauno medinių namų būkle ir pamąstyti apie jų išsaugojimo galimybes. Natūroje apžiūrèta kelios dešimtys Nauja miesčio, Žaliakalnio, Panemunès, Šančių ir Vilijampolès namų, aiškintasi, kaip jie prižiūrimi. Atlikta fotofiksacija, pastebèta unikalių interjero elementų, kurie jokioje apskaitoje nefigūruoja. Tai autentiški baldai, krosnys, langai, durys, lubos, parketo arba lentu grindys. Dalis namų, ypač senesnių, iš carizmo laikotarpio, yra techniškai susidèveję. Tačiau norint, juos dar galima išgelbèti. Kur kas rimčiau nei laikas namus naikina trumparegiška renovacija: sienų apkalimas plastiku, nepriderinto skaidymo plastikiniai langai bei durys, chaotiški paaukštinimai ir priestatai, „euroremontas“ viduje. Daugelis kalbintų namų savininkų saké, kad jaučia sentimentus gyvenamai aplinkai, pasakojo turto paveldèjimų bei praradimų istorijas. Sutikome ir tokių, kurie medinių namų nevertina, skundžiasi paveldosaugininkų suvaržymais. Tapo aišku, jog netinkamą namų tvarkymą visų pirma lemia nepakankamas savininkų informuotumas apie jiems priklausančių medinių namų vertę, saugojimo reikalavimus ir tinkamus priežiūros būdus. Kita vertus, beveik visi šeimininkai stokoja léšų rimtesniems remonto darbams, o ịpareigojimas namą restauruoti gąsdina kaip finansiniu požiūriu nepakeliama užduotis. Nors pripažindami, jog namas vertingas dèl senumo, dauguma savininkų pirmenybę teikia ne išsaugojimui, bet namo atnaujinimui, komfortiško būsto įrengimui. Vykdant projektą studentai atliko preliminarią miestiečių apklausą: 76 proc. respondentų atsakè, jog jiems medinès architektūros išlikimo klausimas yra aktualus, 24 proc. - ne; 85 proc. apklaustụjų mano, jog dèmesys medinès architektūros apsaugai per mažas, ir tik 4 proc. atsiliepé, kad dèmesio pakanka.

Magistrantai gilinosi į Vilniaus medinès architektūros strategijos programą, svarstè, ką iš jos būtų galima perimti ir ką naujo pasiūlyti. Tyrimo pristatymą pateikè diskusijai Kauno architektų namuose. I susitikimą buvo pakviesti medinès architektūros tyrinètojai, paveldosaugininkai, architektai, namų savininkai. Siekta atkreipti visų išsaugojimo veikloje dalyvaujančių visuomenès grupių dèmesị ị nykstančią unikalią medinę miestų architektūrą ir ieškoti realių 
išeičių. Diskusijoje, ị kurią noriai ịsitraukè ir namų savininkai, išsikristalizavo tokie teiginiai:

- Mažiausiomis sąnaudomis medinius pastatus galima išsaugoti, taikant palaikomąji remontą ir nuolatinę būklès priežiūrą.

- Valstybė (savivaldybė) turètų remti medinių namu išsaugojimą, tačiau pagrindinè atsakomybe ir finansine našta vis tiek lieka savininkams; todèl svarbiausia prevencine veikla turètų tapti savininkų motyvacijos skatinimas.

- Savininkas turi jausti pastato vertę. Ją atskleistų edukacija, vykdoma per seniūnijas. Taip pat reikalingas pareigūnų švietimas seniūnijose ir savivaldybèse.

- Tinkamas tvarkymas priklauso ne tik nuo lèšų, bet ir nuo supratimo - būtina konsultuoti savininkus apie medinių namų tvarkymo būdus. Konsultacija turètų būti nemokama ir preventyvi (kol remonto darbams tik ruošiamasi).

- Mokymo įstaigose turètų atsirasti medinès architektūros restauravimo specializacijų - tiek projektavimo darbų, tiek amatininkų atlikejjų.

- Skandinavijos šalių pavyzdžiu reikètų kurti regioninius restauravimo centrus. Jiems pavesti darbu kokybès priežiūrą, atsisakant formalaus specialistų licencijavimo (lemia sugebejimai ir patirtis, o ne licencijos turejjimas).

- Mediniai namai, ypač tie, kurie smarkiai sunykę, turètų būti kruopščiai dokumentuojami (fotofiksacija ir matavimų brěžiniai).

\section{Saugojimo apimtis}

Medinès architektūros savitumas labiausiai išryškètų, jei būtų saugomi ištisi tokių namų arealai. Kol kas Kaune saugomos teritorijos statusą turi tik Žaliakalnio kvartalai prie Gèlių ir Minties Rato g. su 1923 m. suplanuotu veduokliniu gatvių tinklu, medžių eilemis ir vejos juostomis. Čia iki 1940 m. 80 proc. namų buvo mediniai, dabar tokių išlikę apie 70 proc. Techniškai jų visų išsaugoti neįmanoma, nors medinukai kuria šios vietos dvasią (16 pav.). Pagal $2004 \mathrm{~m}$. patvirtintą apsaugos reglamentą saugojimas paliekant galimybę restauruoti taikomas vienuolikai vertingiausių medinių namų, kitiems nustatytas laisvesnis tvarkymo režimas. Saugomos teritorijos statusą netrukus turètų ịgyti kita Žaliakalnio dalis (tarp Perkūno al. ir Kauko laiptų), kurioje taip pat gausu medinių pastatų. Tačiau kitos Žaliakalnio dalys, Ąžuolų kalnas, vadinamoji „Brazilka“, Aleksotas, Vilijampolè, Panemunès ir Šančių teritorijos, kuriose yra daug medinių namų, apsaugos statuso neturi.

Vadinasi, turètų būti galvojama apie bendrą Kauno medinès architektūros išsaugojimo strategiją. Kaip rodo Vilniaus pavyzdys, tokios strategijos planą pa-
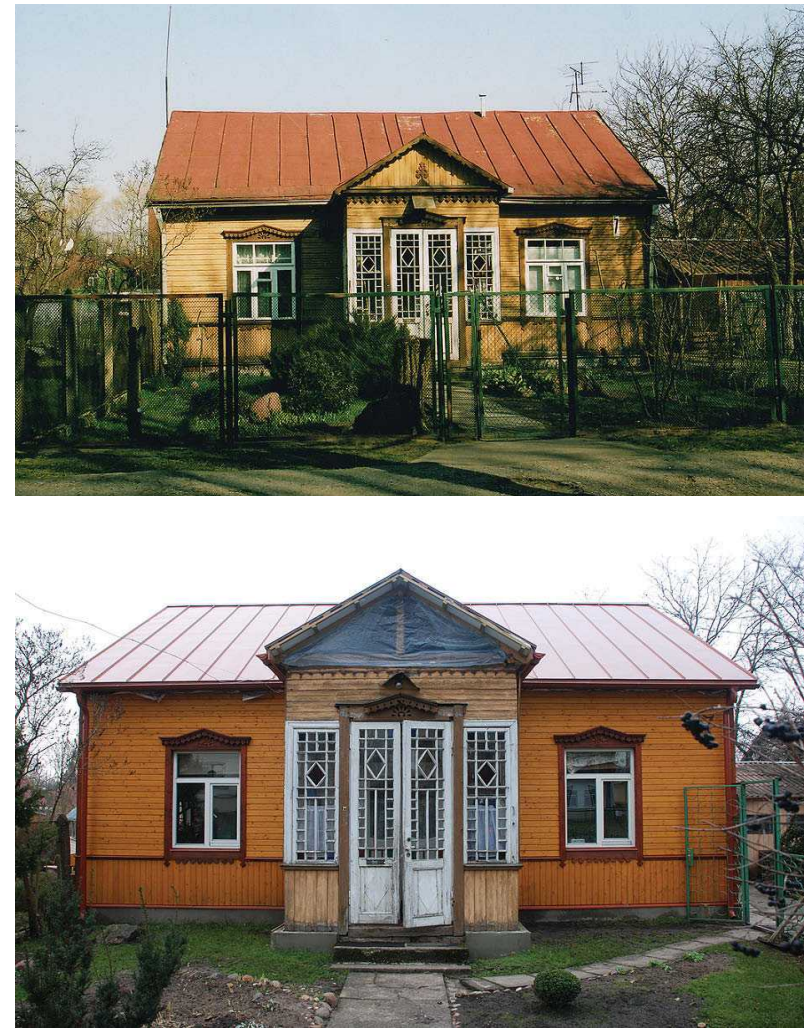

16 pav. Nagingas savininkas pats restauravo namą Žaliakalnyje, Kraševskio g. 7 (priežiūra archit. Liudos Perevičienès)

Fig. 16. A skillful owner restored the house in Žaliakalnis, Kraševskio g. 7 (supervision by architect Liuda Perevičienè)

rengti įmanoma (suregistruojami objektai, numatomi saugojimo režimai), bet, deja, be rimtų finansinių investicijų medinukų atgaivinimo programos nepajuda iš vietos. Praktiniu požiūriu savivaldybei būtų naudingiau globoti geriausiai išlikusius, tipologinę ịvairovę reprezentuojančius pavyzdžius ir koncentruoti jègas ị jų apsaugą bei tvarkymą. Pačių vertingiausių objektų Kaune galètų būti apie 30. Juos reikètų ịrašyti ị Kultūros vertybių registrą ir skelbti saugomais, nes tik tokio statuso objektams galioja finansinio kompensavimo mechanizmas už tyrimo ir restauravimo darbus. Visi kiti statiniai saugotini pagal galimybes, skatinant savininkus rinktis paveldui palankius tvarkymo būdus, išlaikyti autentiškų apdailos ir dekoro detalių pavyzdžius (17-19 pav.).

Kultūros vertybių registre dabar yra 23 mediniai Kauno pastatai. Jie dažniausiai susiję su reikšmingomis asmenybėmis ir visiškai neatspindi tikrosios saugotino medinio paveldo architektūros įvairovès. Be to, net ir registre esančių pastatų (architekto A. Jokimo namas Minties rato g., E. Daugvilienès namas Kauko al.) saugomi tik eksterjerai, o unikalūs interjero elementai tarp vertingųjų savybių neminimi. Senąji interjerą saugoti sudètingiau nei išorès formas, tačiau Skandinavijos šalyse tai daroma. 
Žinoma, nèra ko tikètis, kad valstybè ir savivaldybès imsis plataus medinès architektūros tvarkybos finansavimo. Pagrindinè našta gulè ir guls ant namų savininkų pečių. Jų požiūris ị turimą nuosavybę dažniausiai yra pragmatinis. Sovietiniais metais daugelis privačių namų buvo nacionalizuoti, keitėsi gyventojai, naujai atsikèlę neturejjo intereso ir lěšu juos prižiūrèti. Tokie namai keliauja iš rankų į rankas, juos ịsigiję nauji savininkai stengiasi kuo pigesniais būdais pagerinti gyvenimo sąlygas. Namai be atodairos renovuojami pašalinamos dekoro detalès, profiliuoti sienų apkalai, keičiamos stogų ir sienų medžiagos, dedami plastiko langai ir durys. Šis procesas ypač paspartejjo per paskutinius 10 metų, nes daugelis savininkų èmèsi apšiltinti būstą, keisti susidèvejusią stogų dangą. Tinkama medinių pastatų priežiūra ir restauravimas Lietuvoje dar nèra ịprastas reiškinys. Savininkai nesuinteresuoti
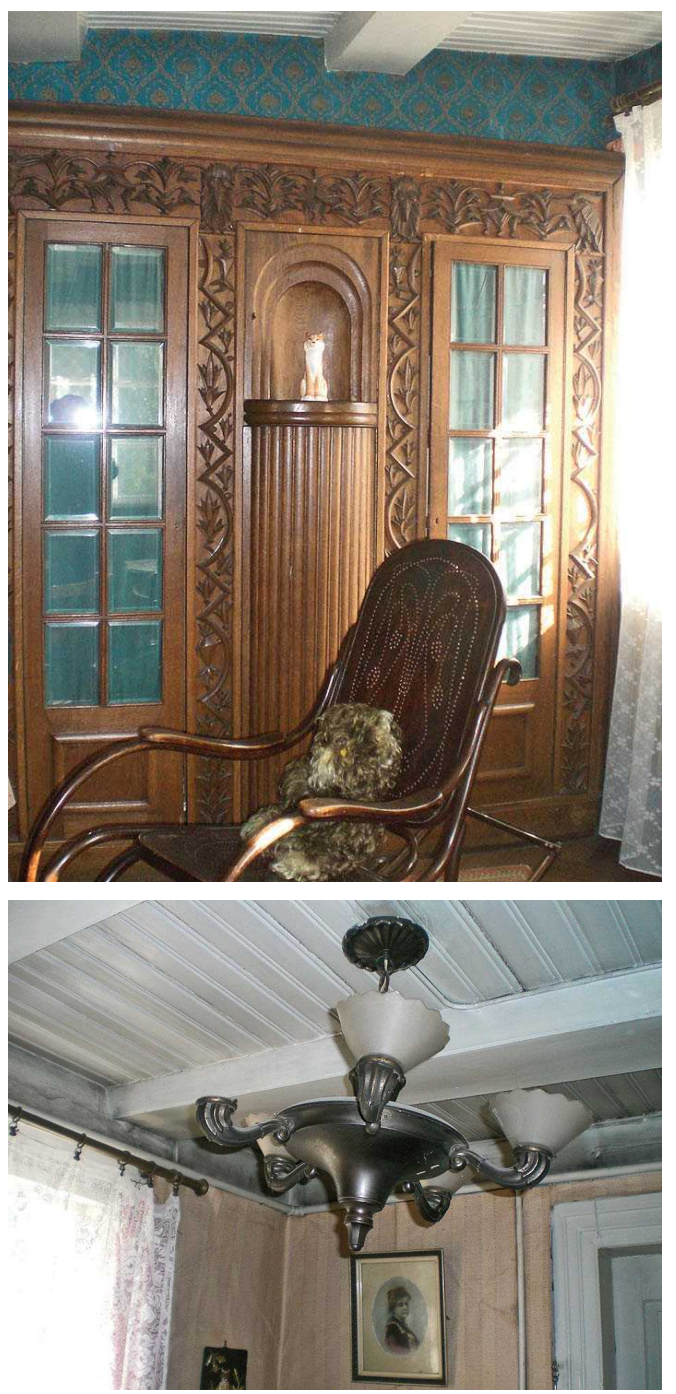

17, 18 pav. Išlikusios autentiškos interjero detalès

Figs 17, 18. The survived authentic interior details brangiai kainuojančiomis natūraliomis medžiagomis, sudetingais dekoro restauravimo darbais, stinga ir amato specifiką išmanančių dailidžių bei architektų. Teko pastebèti, jog namų vertę labiausiai jaučia senbuviai, paveldeję pastatus kaip šeimos nuosavybę. Tokių gyventojų yra Vilijampoleje, Panemunejje, ypač daug Žaliakalnyje.

İrašius ị registrą, reikia vykdyti specialius statinio remonto reikalavimus; savininkas negali taikyti pigesnių tvarkymo būdų, privalo samdyti licencijuotus specialistus. Tinkamas restauravimas reikštų buvusių formų ir elementų atkūrimą naudojant tas pačias medžiagas ir jų apdorojimo techniką. Autentiška laikoma tokia nauja medžiaga, kurios rūšis, sandara, faktūra, spalva atitinka pirmines buvusios medžiagos savybes. Nors atkartotos dalys neturi laiko patinos ženklų, taip atnaujintas statinys pripažistamas autentišku.

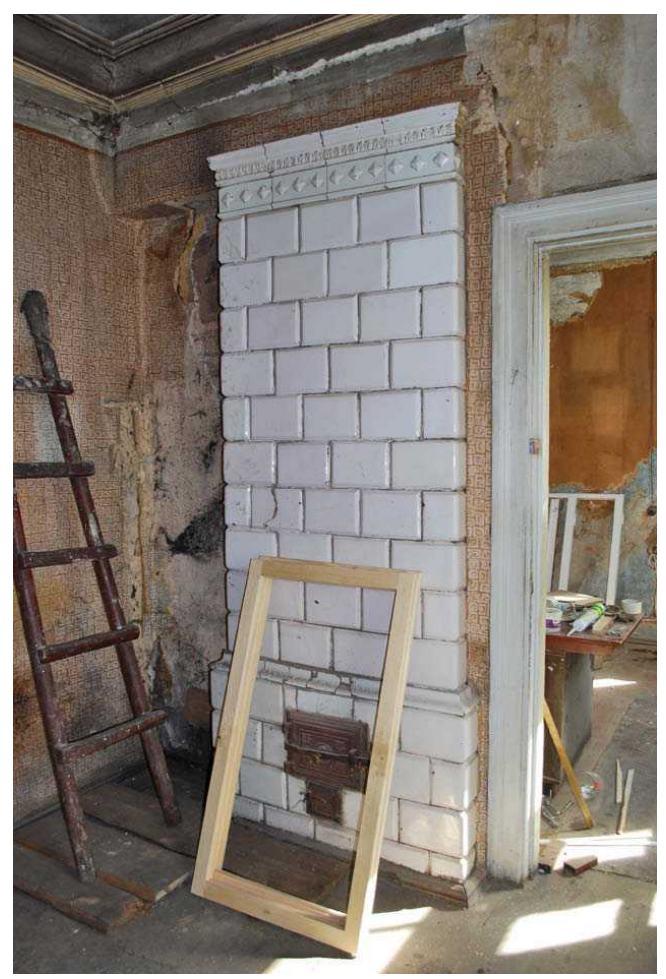

19 pav. XIX a. pabaigos name, neįrašytame i Kultūros vertybių registrą, savininkai savo iniciatyva restauruoja interjero elementus

Fig. 19. The owners of a house that is not included on the Register of Cultural Property carefully restore interior elements on their own initiative 


\section{Medinès architektūros verčiu atskleidimo niša}

Minèti saugojimo sunkumai ragina imtis švietejiiškos misijos - skleisti žinias apie medinès architektūros paveldo išsaugojimo tikslą ịvairiomis formomis, ̨̣vairioms auditorijoms. Namų savininkai turètų būti išsamiai informuojami apie jiems priklausančio paveldo objekto vertę ir saugojimo apimtị. Savivaldybès savo ruožtu turètų kontroliuoti naujų stambių objektų planavimą tarp sodybinių namų, nes tai smarkiai keičia tradicinę aplinką.

Kol kas namu savininkams, tvarkantiems medinius pastatus, trūksta kvalifikuoto konsultavimo. Vertètų suburti konsultantų savanorių tarnybą, ị kurią įsitrauktų ne tik ekspertai, bet ir paveldo bei architektūros specialybių studentai. Savanoriai padètų savininkams sutvarkyti projektinę dokumentaciją, parinkti tinkamas medžiagas, dažymo, apšiltinimo technologijas, kur įmanoma, patartų rinktis palaikomąją priežiūrą, o ne radikalų atnaujinimą. Siūloma kurti Medinès architektūros išsaugojimo bendruomenę Kaune, kurioje bendradarbiautų namų savininkai, paveldo specialistai, amatininkai. Per ją galètų steigtis informacinis tinklas, padedantis rasti tvarkymo specialistus. Kasmet vertètų atrinkti ir nominuoti geriausiai sutvarkytus medinius namus. Savaime aišku, jog ne visi miestiečiai linkę gyventi senuose medinukuose tokios veiklos entuziastus reikètų skatinti, o norintiems modernaus būsto turètų būti sudaromos galimybès kurtis ne paveldo teritorijos zonoje.

Tradicinis miestovaizdis yra mūsų istorijos dalis. Jei žmonès nustoja branginti ankstesnių kartų palikimą, jie pamažu tampa abejingi viskam, kas matuojama ne pinigais ir prestižu. Mūrinè ir medinè, profesionalioji ir lokalinè architektūra privalo darniai gyvuoti kartu. Esame atsakingi už autentiškų praeities liudininkų išsaugojimą. Todèl ypač svarbūs tokie sumanymai, kaip dailininko Andriaus Surgailio fotografijų knygos. Dažno miestiečio žvilgsnis į medinius namus yra perdèm pragmatiškas, o jos padeda atverti kitokius matymo kampus. Unikalu, jog Kauno namai tapo ¡kveépimo šaltiniu atstovui iš turtingo kultūros paveldo šalies: tai, ką daro prancūzų dailininkas Gilles Vuillard (Žilis Viujaras), jau dešimti metai gyvenantis Kaune (https://www.paveikslai.lt/lt/dailininkai/gilles-vuillard/), reiškia kur kas daugiau nei signalą apie nykstanti paveldą. Per jo paveikslus medinukų vertė deklaruojama tarptautineje erdveje, esame skatinami iš naujo atrasti Žaliakalnio ir kitų rajonų romantiškąjj (ir drauge - ekologinị) pradą. Kauno kvartaluose, jeigu jie būtų tvarkomi, Vuillard įžiūri „mažosios medinès Italijos" viziją. Jo mintis, kad medinè architektūra yra tarsi Lietuvos parašas, galètų tapti moto naujos kartos saugojimo strategijai.

\section{Išvados}

1. Miestų medinèje architektūroje susijungè profesionaliosios ir etninès (miesto, dvaro, kaimo) kultūros tradicijos. Dèl to ji saugotina kaip išskirtinè lokalinio tapatumo perdavejja.

2. Kaune išliko medinių dvarelių, sodybinių namų, vilų, kotedžų, vasarnamių, nuomojamų namų, kariškių ir geležinkeliečių gyvenamųjų kompleksų. Reikètu išsaugoti visų tipologinių grupių architektūros reprezentantus Naujamiesčio, Žaliakalnio, Aleksoto, Panemunès, Šančių, Vilijampolès medinių na mų arealuose.

3. Oficiali valstybės politika jau 10 metų skelbia tuos pačius medinès architektūros išsaugojimo uždavinius - organizuoti objektų nustatymą ir dokumentavimą, itteisinti palankaus kreditavimo bei kompensavimo sistemą, saugoti paveldą remiant kaimo ir miesto bendruomenes, integruoti medinio paveldo apsaugą $i$ vietovių planavimą, parengti statinių tvarkymo metodiką, pavyzdžių katalogus, skatinti tradicinius amatus. Idèjos tinkamos, tačiau politika neveiksni dèl suinteresuotų vykdy tojų stokos ir silpno finansinio pagrindo.

4. Kaip parodè $2009 \mathrm{~m}$. Vytauto Didžiojo universiteto Menu fakultete vykęs edukacinis projektas, medinių namų išsaugojimas daugiausia priklauso nuo savininkų supratingumo ir motyvacijos. Todèl savininkų patraukimas ị medinio paveldo rèméjų pusę laikytinas svarbiausia išsaugojimo sąlyga. Siekiant ugdyti vertès suvokimą, siūloma ieškoti naujų paveldo atskleidimo būdų (seminarai savininkams, architektams, savivaldybès, seniūnijų pareigūnams, savanorių tarnystè ir kitos socialinio bendravimo formos).

5. Tinkamą tvarkymą lemia ne vien pinigų kiekis, bet ir kryptinga informacija: reikètų iš anksto konsultuoti medinių namų savininkus apie paveldui palankią priežiūrą ir tvarkymą. Mediniais namais suinteresuota bendruomene galètų kurtis ir dalintis informacija virtualioje aplinkoje.

6. Medinè architektūra trapi, greitai nykstanti, tačiau medis yra natūraliai atsinaujinanti medžiaga, pastato elementus lengva pakeisti. Jai tvarkyti būtini techniniai resursai - architektūros restauratorių, dailidžių ir kitų tradicinių amatų meistrų ugdymas, paslaugų tinklo organizavimas.

7. Lietuvos valstybeje reiketų sukurti realias teisines ir praktines galimybes atgaivinti senus medinius namus tiems, kas nori šia veikla užsiimti. Finansiniu pagrindu galettų tapti medinius namus tvarkančių savininkų rèmimas taikant mokesčių lengvatas. 


\section{Literatūra ir šaltiniai}

Drèma, V. 1991. Vilniaus Šv. Onos bažnyčia. Vilniaus katedros rekonstrukcija 1782-1801 m. Vilnius: Mokslas.

Filipavičienè, G. ir kt. 2004. Vilniaus miesto centrines dalies medinès architektūros paveldas. Medinès architektūros paveldo apsaugos strategijos metmenys. UAB „Senojo miesto architektai“. D. Puodžiukienès asmeninis archyvas.

Jomantas, A. Patarimai [interaktyvus], [žiūrèta $2010 \mathrm{~m}$. vasario 25 d.]. Prieiga per internetą: <http://www.kpd.lt/ patarimai>.

Jurevičienè, J. 2002. Medinè architektūra istoriniame priemiestyje. Vilniaus Užupio autentiškumas, Urbanistika ir architektūra [Town Planning and Architecture] 26(1): 11-17.

Kauno miesto savivaldybès 1-ojo Žaliakalnio kultūrinio draustinio specialiojo plano pagrindžiamoji dalis: Kultūrinio draustinio teritorijos tyrimai, paveldo sauginiu verčiu nustatymas ir pasiūlymai saugojimui. 2007. 130 p., 8 brèž. Autorès asmeninis archyvas.

Kultūros ministro isakymas Nr. IV-30 „Dèl Medinès architektūros paveldo išsaugojimo 2008-2010 m. programos ir Medinès architektūros paveldo išsaugojimo 2008-2010 m. programos igyvendinimo priemoniu plano patvirtinimo" [interaktyvus], $2008 \mathrm{~m}$. sausio mèn. 24 d. [žiūrèta $2011 \mathrm{~m}$. vasario 23 d.]. Prieiga per internetą: <http://www.kpd.lt/ lt/node/472>.

KVAD direktoriaus ịsakymas Nr. I-35 „Dèl etnoarchitektūros vertinimo kriteriju ir tvarkos patvirtinimo", 6 skirsnis (autentiškumas) [interaktyvus], $2004 \mathrm{~m}$. vasario $20 \mathrm{~d}$. [žiūrèta $2010 \mathrm{~m}$. vasario $25 \mathrm{~d}$.]. Prieiga per internetą: $<\mathrm{http}: / / \mathrm{www}$. $\mathrm{kpd} . \mathrm{lt} / \mathrm{lt} /$ node/216>.

KM 2008-01-24 įsakymas Nr. IV-30 „Dèl Medinès architektūros paveldo išsaugojimo 2008-2010 metu programos ir Medinès architektūros paveldo išsaugojimo 2008-2010 metu programos igyvendinimo priemoniu plano patvirtini$m o$ " [žiūrèta $2010 \mathrm{~m}$. vasario $26 \mathrm{~d}$.]. Prieiga per internetą: $<$ http://www.kpd.lt/lt/node/472>.

Lietuvos architektūros istorija. Nuo XIX a. II dešimtmečio iki 1918 m. 2000. T. III. Vilnius: Savastis.

Lietuvos Respublikos Valstybinès kultūros paveldo komisijos sprendimas „Dèl Lietuvos medinio kultūros paveldo išsaugojimo“" [interaktyvus]. $2006 \mathrm{~m}$. birželio $28 \mathrm{~d}$. [Nr.] S-2-(118) [žiūrèta $2011 \mathrm{~m}$. vasario 23 d.]. Prieiga per internetą: <http://www3.lrs.lt/pls/inter3/dokpaieska. showdoc_l?p_id=280422\&p_query=\&p_tr2 $>$.

Lietuvos Respublikos Valstybinès kultūros paveldo komisijos sprendimas „Dèl Lietuvos mediniu statiniu ir etnografiniu kaimu kultūros paveldo išsaugojimo“ [interaktyvus]. 2010 m. balandžio mèn. 30 d. [Nr.] S-5(159), [žiūrèta $2010 \mathrm{~m}$. vasario 25 d.]. Prieiga per internetą: $<\mathrm{http}: / /$ www3.lrs.lt/pls/inter3/dokpaieska.showdoc_l?p_ $\mathrm{id}=371589 \&$ p_query $=\& p \_t r 2>$.

Lietuvos Respublikos Valstybinès paminklosaugos komisijos sprendimas „Dèl medinio kultūros paveldo išsaugojimo“ [interaktyvus]. $2002 \mathrm{~m}$. rugsèjo $13 \mathrm{~d}$. [Nr.] 88 [žiūrèta $2010 \mathrm{~m}$. vasario 25 d.]. Prieiga per internetą: $<$ http:// www3.lrs.lt/pls/inter3/dokpaieska.showdoc_p?p_ id $=188726>$.

Lukšionytė-Tolvaišienè, N. 2000. Istorizmas ir modernas Vilniaus architektūroje. Vilnius: VDA leidykla.

Lukšionyte-Tolvaišienè, N. 2001. Gubernijos laikotarpis Kauno architektūroje. Kaunas: VDU leidykla.
Lukšionytė-Tolvaišienė, N. 2005. Kauno Žaliakalnio reglamentas ir tvarios raidos nuostatos, iš Meno istorija ir kritika. T. 1 [interaktyvus]. Kaunas: VDU leidykla, 24-31 [žiūrèta $2010 \mathrm{~m}$. vasario $25 \mathrm{~d}$.]. Prieiga per internetą: $<$ http://www.vdu.lt/Leidiniai/MIK/index.html>.

Medinè architektūra Lietuvoje. 2002. Vilnius: Vaga.

Miškinis, A.; Steponaitytè, N. 1995. Kauno miesto kultūros paveldo tyrimai ir principiniu siülymu paveldo vertybèms tvarkyti parengimas. Dalis: Medinès architektūros tyrimai, vertybinè charakteristika, saugojimo ir tvarkymo siūlymai. KMS Miesto plètros departamento Kultūros paveldo skyriaus archyvas.

Puodžiukienè, D. ir kt. 2005. Vilniaus miesto centrinès dalies medinès architektūros paveldo pastatu atrinkimas techniniu apsaugos priemoniu, remonto, konservavimo restauravimo darbams. UAB „Senojo miesto architektai“. D. Puodžiukienès asmeninis archyvas.

Ptašek, M. 2002. Medinè architektūra Vilniaus Žvėryno rajone, iš Medinè architektūra Lietuvoje. Vilnius: Vaga, 89-93.

Sokołowski, M. 1906. Dwa gotycyzmy: wileński i krakowski w architekturze i złotnictwie i źródła ich znamion charakterystycznych, iš Sprawozdania Komisyi do badania Historyi Sztuki Akademii Umiejętności w Krakowie, T. VII. Kraków: nakladem AU, 35-40.

Surgailis, A. 2006. Medinis Vilnius [Wooden Vilnius] (tekstas L. Laučkaitès). Vilnius: Versus aureus.

Surgailis, A. 2008. Medinis Kaunas [Wooden Kaunas] (tekstas N. Lukšionytės-Tolvaišienès). Vilnius: Versus aureus.

Vilniaus senamiesčio atnaujinimo agentūra, steigimas ir veikla [interaktyvus], [žiūrèta $2010 \mathrm{~m}$. vasario 25 d.]. Prieiga per internetą: <http://www.vsaa.lt/med_10taisykl.htm>.

Vilniaus miesto savivaldybès tarybos sprendimas Nr. 1-1117 „Dél medinès architektūros paveldo apsaugos strategijos igyvendinimo programos tvirtinimo" [interaktyvus], $2006 \mathrm{~m}$. balandžio mèn. $26 \mathrm{~d}$. [žiūrèta $2010 \mathrm{~m}$. vasario 25 d.]. Prieiga per internetą: <http://www.vilnius.lt/vaktai/Default.aspx? Id=3\&DocId=30130626 $>$.

\section{WOODEN ARCHITECTURE IN CITIES: OPPORTUNITIES FOR PRESERVING}

\section{N. Lukšionytè}

Abstract. Institutions for Lithuania's heritage protection have been declaring the necessity of preserving wooden architecture since 2002; however, there have been very few realistic results. Although the Vilnius City Municipality initiated a strategic programme for saving wooden architecture, there have been no tangible results to date.

The purpose of this article s to analyse the needs and opportunities for preserving wooden architecture in Kaunas. Wooden buildings such as small manor and garden estate houses, villas, cottages, summer homes, rental houses and residential military and railway complexes have survived in Kaunas. Representative buildings of all these types need to be preserved in all parts of Kaunas. These reflect the juncture of professional and ethnic traditions in cities, estates and villages. Therefore such buildings are exceptional at conveying local identity.

The 2009 educational project carried out at the Faculty of Arts of Vytautas Magnus University revealed that the survival of wooden houses largely depends on the motivation of 
their owners. The most important condition for preserving wooden architecture is to attract the owners of these buildings to join with the supporters of this architectural heritage. Consultations on the maintenance of such buildings to retain the heritage must be organised. The community interested in rehabilitation of wooden structures could generate and share information in a virtual environment.

Keywords: wooden houses, architectural heritage, Kaunas.

\section{NIJOLE் LUKŠIONYTE்}

A professor at the Faculty of Arts, Vytautas Magnus University, Laisves al. 53, LT-44309 Kaunas, Lithuania.

E-mail:n.luksionyte@mf.vdu.lt

$\mathrm{PhD}(\mathrm{Hp})$ in Humanities. Research interests: history of Lithuanian architecture of the $19^{\text {th }}$ and 20th c., Lithuanian cultural heritage-theory and practice. Teaching courses: Architectural Heritage protection, Cultural Policy, Analysis of Architectural object.

Nuotraukos: I. Veliutès, L. Baublienès, I. Taparauskaitès (2009), N. Lukšionytès (2007). 